\title{
Irrigation water quality and Microbial Safety of Leafy Greens in Different Vegetable Production Systems: A Review
}

\author{
MOSIMANEGAPE JONGMAN \& LISE KORSTEN*
}

\begin{abstract}
Department of Plant Science, Faculty of Natural and Agricultural Sciences University of Pretoria, Private bag X20, Hatfield, Pretoria, 0082, South Africa

* Corresponding author. Tel: +27 124204097.

Email addresses: jongmanmp@gmail.com (M. Jongman), lise.korsten@up.ac.za (L. Korsten).
\end{abstract}

\begin{abstract}
Access to large sources of quality water for irrigation is fundamental to the hygienic cultivation of fresh produce. However, due to factors such as contamination of water bodies, access to clean uncontaminated water is fast becoming an ever increasing global challenge. The unavailability of quality source water increases the risk of contamination of fresh produce with human pathogenic microorganisms, which may compromise public health. Over the past few years, there has been a decline in the microbiological quality of surface water and other sources used for irrigation. This is mainly due to upstream faecal contamination. Therefore, the assessment and subsequent suitability of alternative water sources for irrigation such as roof harvested rainwater should be considered. Contrasting views regarding the quality of roof harvested rainwater (RHRW) have been published. Pathogens such as Salmonella and Campylobacter species and Listeria monocytogenes have been reported in RHRW. Leafy green vegetables such as cabbage, spinach and lettuce are produced across a wide range of farming systems from
\end{abstract}


regulated formal (commercial farms) to informal (small-scale and homestead gardens) setups. This review will discuss global water challenges associated with irrigation water, microbial quality of source water for irrigation, crop contamination, and pathogen detection and characterization methodologies.

Keywords: Food safety, Foodborne pathogens, Fresh produce, Irrigation water sources, Pathogen detection systems.

\section{Introduction}

One of the increasing major problems faced with the cultivation and consumption of ready-to-eat fresh produce has been the escalating rates of disease outbreaks. ${ }^{(1)}$ Leafy green vegetables such as cabbage, baby spinach and lettuce have been classified by the World Health Organization ${ }^{(2)}$ as a priority focus area relating to the safety of fresh produce from a global perspective. This is mainly due to the increased consumption of these raw vegetables and the frequency of disease outbreaks associated with leafy green vegetables.

Leafy green vegetables are cultivated across different production systems ranging from large-scale commercial ${ }^{(3)}$ to small-scale farms,${ }^{(4)}$ as well as homestead gardens. ${ }^{(5)}$ General good agricultural practices such as GLOBALG.A.P. requirements have been implemented in commercial farms and contribute to a lower risk of associated outbreaks. ${ }^{(6)}$ Under-reporting of foodborne illness outbreaks associated with the farm-to-fork continuum have been highlighted by some authors. ${ }^{(7)}$ One common challenge of primary production across farming systems is the contamination of fresh produce with waterborne pathogens, arising from contaminated source water for irrigation. ${ }^{(1)}$ 
It is therefore important to note that water is a significant source of contamination of food produce; for this reason, much attention has been given to the role of irrigation water in fresh produce supply chains. ${ }^{(1)}$ Sources of water used for irrigation include rivers, ${ }^{(8)}$ borehole, harvested rain water ${ }^{(9,10)}$ and groundwater. Roof harvested rainwater (RHRW) offers an alternative to relieve pressure on existing natural scarce water sources. ${ }^{(9)}$ The probability that these sources of water will be contaminated by human pathogens varies considerably depending on several factors ${ }^{(11)}$ such as surface runoff. Pathogens causing diseases in humans such as Yersinia enterocolitica, verocytotoxin-producing Eschericha coli, Salmonella species (spp.), and Shigella spp. ${ }^{(12)}$ as well as opportunistic pathogens ${ }^{(13)}$ have been detected in irrigation water.

Various techniques for microbial detection have evolved over the years resulting in a paradigm shift for diagnostics. ${ }^{(14)}$ The conventional viable culture method for detecting microbial pathogens in both irrigation water and fresh produce are being supplemented by rapid molecular approaches. $^{(15)}$ New methods for the detection $(\mathrm{PCRs})^{(13)}$, characterization $^{(16)}$ and identity confirmation (matrix-assisted laser desorption ionization time of flight mass spectrometry) ${ }^{(17)}$ of pathogens are being developed in an effort to overcome the limitations such as accuracy and sensitivity of the conventional culture techniques. ${ }^{(10)}$ The rapid characterization of such pathogens, including phylloplane inhabitants, is imperative to food safety research and epidemiology. Therefore, this paper reviews food safety issues associated with irrigation water sources and safety of leafy green vegetables at different production systems ranging from commercial, small-scale and homestead gardens. Pathogen detection systems will also be discussed in this review. 


\section{Global Water Challenges}

The high demand for fresh water supplies is increasing as population growth continues to spiral out of control. ${ }^{(9)}$ High demand for safe quality water is accompanied with challenges to provide clean potable supplies that minimize public health concerns. ${ }^{(18)}$ This growing demand for water 'fit-for-purpose' is further complicated by the rapid increase in urbanization, industrialization, global warming and the impact of climate change on water source. Most regions around the world are either faced with the challenge to address freshwater shortages or prevent further pollution of the readily available water resources. ${ }^{(19)}$ Disease outbreaks linked to the microbiological quality of water is also an important public health concern. Between 1999-2000 in the United States of America, a total of 39 disease outbreaks and an estimated 2,068 illnesses associated with drinking water were reported by Lee et al. ${ }^{(20)}$ These global challenges are threatening to reduce agricultural yields and further increase the contamination of various water sources.

\section{Irrigation Water Sources}

Different sources of water for irrigation exist and these include groundwater, municipal water, rainwater, ${ }^{(21)}$ surface water, ${ }^{(8)}$ and wastewater. ${ }^{(22)}$ Despite not being generally available and expensive, municipal water is considered clean and potable. Groundwater and rainwater are also known sources of quality water while surface water are often considered polluted. ${ }^{(1)}$ However, in many countries, the use of municipal water for irrigation is not encouraged due to water shortages. Ensuring the quality of all water sources is a constant challenge in a global and regional context. 


\section{Surface Water}

Surface water includes water found in lakes, ponds, rivers, streams, and other natural watercourses. ${ }^{(23)}$ This valued resource provides water used for drinking and domestic use, irrigation, industrial and for recreational purposes. Although frequently replenished through precipitation, surface water is lost through evaporation and escape into the ground. Surface water sources are also frequently polluted by storm water runoff, animal fecal material or sewage effluent. ${ }^{(8)}$ The microbiological quality of lake water is often considered better than those found in rivers. However, the latter has inconsistent quality fluctuations based on upstream and adjacent activities and changing weather patterns. ${ }^{(1)}$

\section{Groundwater}

Groundwater is generally of high-quality fresh water. Globally, ground water is the source of one third of all freshwater withdrawals, supplying an estimated $42 \%$ of the water used for agricultural purposes. ${ }^{(24)}$ In South Africa, ground water accounts for $13 \%$ of all freshwater sources but two thirds of the population is largely dependent on it. ${ }^{(25)}$ The agricultural sector uses about $80 \%$ of the groundwater for irrigation purposes in the South Africa ${ }^{(26)}$ making it a critical water source. However, groundwater supplies are diminishing ${ }^{(27)}$ in many parts of the world; thus, increased use of surface water is required. Such a trend leads to use of water sources that have a greater prevalence of pathogen contamination.

\section{Wastewater}

The microbiological quality of wastewater is very poor; hence, there is a need for extensive treatment preceding its use for irrigation purpose. Studies have shown that only an estimated 
$10 \%$ of wastewater is effectively treated in countries with emerging economies. ${ }^{(1)}$ Therefore, this water source is generally not recommended to be used for agricultural purpose, since it contains pathogenic microorganisms of public health concern. ${ }^{(28)}$ Reclaimed water has also been used for irrigation of fresh produce, leafy greens included. ${ }^{(29)}$ However, there is public perception that irrigation with reclaimed wastewater decreases microbiological food safety leading to its prohibited use on agricultural products that will be consumed by the public.

\section{Rainwater Harvesting}

Rainwater harvesting (RWH) is a suitable alternative source of freshwater that could assist in providing for the ever-increasing demand for water. ${ }^{(10,30)}$ Roof harvested rainwater (RHRW) and ground surface harvested rainwater (GHRW) are the two systems by which water is collected from roof-tops or ground surface runoff and stored in above-ground or underground tanks. ${ }^{(10)}$ The quality of rainwater partly depends on the system through which water is collected. This can be demonstrated with RHRW, which can be polluted by pathogenic bacteria originating from animal droppings and other debris on roof-tops. ${ }^{(9)}$ Possible uses of this source water include drinking or irrigation of domestic food gardens. ${ }^{(31)}$ People in rural areas are increasingly dependent on river water for drinking and GHRW for irrigation purposes. However, due to increased levels of river pollution, ${ }^{(8)}$ people dwelling in rural communities who are deprived access to municipal or borehole water, are thus dependent on this water source. The use of GHRW for irrigation of crops highlights an increased risk of pathogen contamination associated with this practice. ${ }^{(32)}$ This may result from numerous reintroduction events of pathogens such as Salmonella from domesticated animals such as cattle and other wildlife. 


\section{Importance and Microbial Quality of Irrigation Water Sources}

In many developing countries such as India, irrigation accounts for over $90 \%$ of available water sources for agriculture. ${ }^{(33)}$ In developed nations such as England, water used for irrigation accounts for $1 \%$ of water withdrawn from available sources. Yet, water used for irrigation in other developed countries such as Spain and Portugal exceeds 70\% of total usage. ${ }^{(33)}$ However, water requirements for irrigation in South Africa are significant, representing about $70 \%$ of the total water use within the agricultural sector. ${ }^{(31)}$ It is important to note that amount of water used for irrigation may not be dependent on development but in this case climate.

In the past more attention was given to the microbial quality of drinking water systems, with fewer concerns about surface water (rivers, streams, etc.) and other natural water sources. ${ }^{(35)}$ This has led to the decline in the quality of surface water. ${ }^{(36)}$ In many developing countries, the poor quality of surface water is largely due to absence and/or poor maintenance of sanitary amenities and poorly serviced informal settlements in close proximity to the rivers. ${ }^{(8,37)}$

Several rivers in South Africa such as the Jukskei, Umungeni and the Berg River, were reported to have high levels of Escherichia coli (E. coli) exceeding the current national regulatory standards $(1,000$ E. coli $\mathrm{CFU} / 100 \mathrm{ml})$ set by the Department of Water Affairs and Forestry. ${ }^{(38)}$ Similar results were reported in two Norwegian rivers where samples exceeded the minimal concentrations of E. coli in irrigation water sources. ${ }^{(39)}$ Gemmell and Schmidt ${ }^{(8)}$ evaluated the microbiological quality of the Msunduzi River in South Africa used for crop irrigation and other domestic purposes, and detected total coliforms of 490 and 84,000 MPN/100 $\mathrm{ml}$, E. coli up to 7,900 MPN/100 ml and Salmonella spp. over a 13 month period. From their study, it was concluded that the water of Msunduzi River is microbiologically poor and does not 
fulfill the Department of Water Affairs and Forestry guidelines for safe irrigation water for cultivating ready to eat raw food. The reports from this research show that some sources of surface water in South Africa are polluted, yet are still used for irrigation by commercial, smallscale and homestead production systems.

The sudden shift towards the use of RHW as a viable alternative is due to the realization that the conventional sources of water are increasingly constrained and becoming unsuitable for irrigation and domestic purposes. ${ }^{(10,40)}$ Although the use of RHW is widely recognized for potable purposes, its application for irrigation purposes has not been fully explored. This is despite the fact that it is a feasible option to increase water productivity and therefore crop yields. $^{(41)}$

\section{Surface Water and Rooftop Harvested Rainwater Quality in Agriculture}

Despite earlier reports considering RHRW to be safe and its compliance with international standards for quality drinking water, ${ }^{(42)}$ subsequent studies have since reported the presence of chemical and/or microbial pollutants at levels above the accepted international standard. ${ }^{(9,10,43)}$ Chidamba and Korsten ${ }^{(10)}$ attributed the disparities in these findings to the varying environmental characteristics prevailing in the area. As a result, there is a rise in public health concerns about the quality of water and the ensuing potential risks due to the presence of pathogens.

Rainwater harvested from ground surface runoff (GHRW) can positively improve rainfed agriculture, presenting prospects and opportunities that are almost certainly affordable to small-scale farmers. ${ }^{(44)}$ Despite its positive prospects, GHRW has pollution pathways parallel to those of conventional surface water sources. A widespread range of contaminants including dust, soil, tree leaves, adjacent industrial units, and animal faeces such as birds and insects that access 
the ground pose a potential health risk if the collected water is untreated and used for irrigation of crops if the produce are to be consumed raw like leafy green vegetables.

\section{Pathogens in Irrigation Water}

Bacterial pathogens such as Salmonella spp. have been detected in irrigation water. ${ }^{(45)}$ Chigor et $a l{ }^{(46)}$ detected E. coli $\mathrm{O} 157$ in $2 \%$ of river water samples from northern Nigeria used for irrigation. A study by Benjamin ${ }^{(47)}$ reported that E. coli $\mathrm{O} 157: \mathrm{H} 7$ was present in streams and tributaries in a leafy green production region of California; however, the pathogen was not detected in irrigation water prior to the point of contact with produce. Aeromonas spp., Campylobacter spp., Listeria spp., Salmonella spp. ${ }^{(9,10,43,48)}$ and conventional faecal indicator systems, E. coli ${ }^{(13)}$ and faecal coliforms, which are a source of public health concern, have been detected in alternative irrigation water sources such as RHRW. During precipitation, pathogens are washed into the rainwater tanks, although Sanchez et al. ${ }^{(49)}$ stated that fresh rainwater already contain some microbes prior to falling on the roof-tops. In their recent review, Sanchez et al. ${ }^{(49)}$ indicated that RHRW harbors pathogens such as Legionella spp., Salmonella spp. and Campylobacter spp. capable of causing illnesses. The presence of these pathogens in irrigation water is a concern for leafy green vegetables consumed raw.

\section{Leafy Green Vegetables}

Leafy greens are vegetables that are cultivated for the consumption of their edible leaves; they include, among others, spinach, turnip, cabbage, parsley and lettuce. ${ }^{(2)}$ This review focuses on three leafy green vegetables, cabbage, lettuce and spinach. Cabbage (Brassica oleracea var. capitata) is believed to have originated from the coast of the North Sea, the English channel and 
northern Mediterranean ${ }^{(50)}$ while lettuce (Lactuca sativa) originated along the east of the Mediterranean. ${ }^{(51)}$ Baby Spinach, Spinacia oleracea, originated in the Persian area (now Iran) and was introduced into North Africa, and later taken into Europe. These leafy green vegetables are now globally cultivated and commonly consumed. Global annual production of cabbage is approximately 72 million metric tonnes in 2014 representing $60 \%$ of all leafy green vegetable produce. This is followed by lettuce of approximately 25.2 million metric tonnes and baby spinach 22.8 million metric tonnes. ${ }^{(52)}$ The major producers of these crops are China and the United States of America, which produce about 72 million metric tonnes, representing $60 \%$ of the annual global production. ${ }^{(52)}$

In contrast, the African continent accounts for a mere $3.78 \%$ of the global annual production of these leafy green vegetables (Figure 1). South Africa for instance, produces less than 10,000 and approximately 30,000 tonnes of spinach and lettuce respectively, with an average annual growth rate of $1 \% .^{(52)}$ The average production capacity of cabbage in South African was just above 200,000 metric tonnes in 2014. 


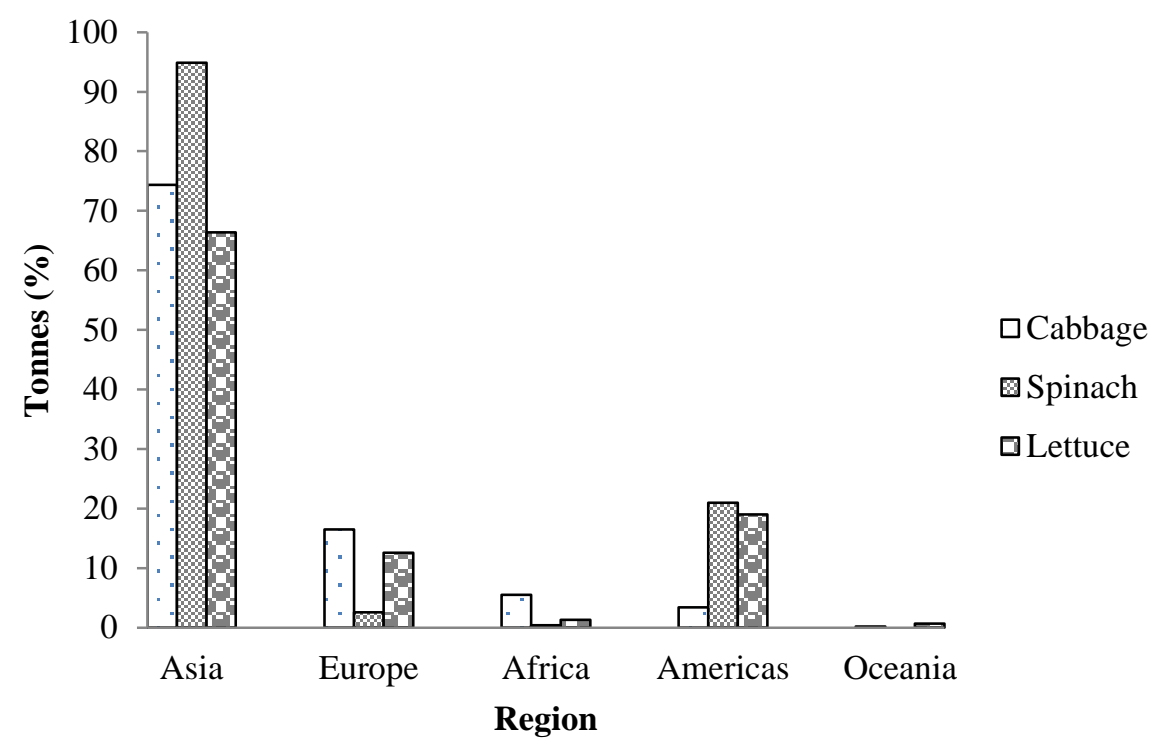

Figure 1. Percentage of total water used for irrigation in selected countries.

\section{Leafy green vegetable production systems}

For the purpose of this review, three production systems, namely commercial and small-scale farming, as well as homestead gardens will be discussed.

\section{Commercial farming}

Commercial farming can be defined as the production of agricultural products intended for the market to be sold at commercial structures and/or sold to end consumers, fellow farmers and/or direct exports. ${ }^{(53)}$ These farms usually use high levels of inputs such as greenhouses and other high-tech equipment. In South Africa commercial farmers provide $80 \%$ of South-African agricultural output. Several studies have been conducted regarding food safety at leafy green vegetable commercial farming systems. ${ }^{(54)}$ Research concerning food safety (search keywords: foodborne pathogens, leafy greens, commercial farms) at commercial farms has been increasing 
with about 60\% of peer reviewed publications between 2010 and 2015 (Figure 2). However, more research is required due to sporadic foodborne disease outbreaks linked to leafy greens.

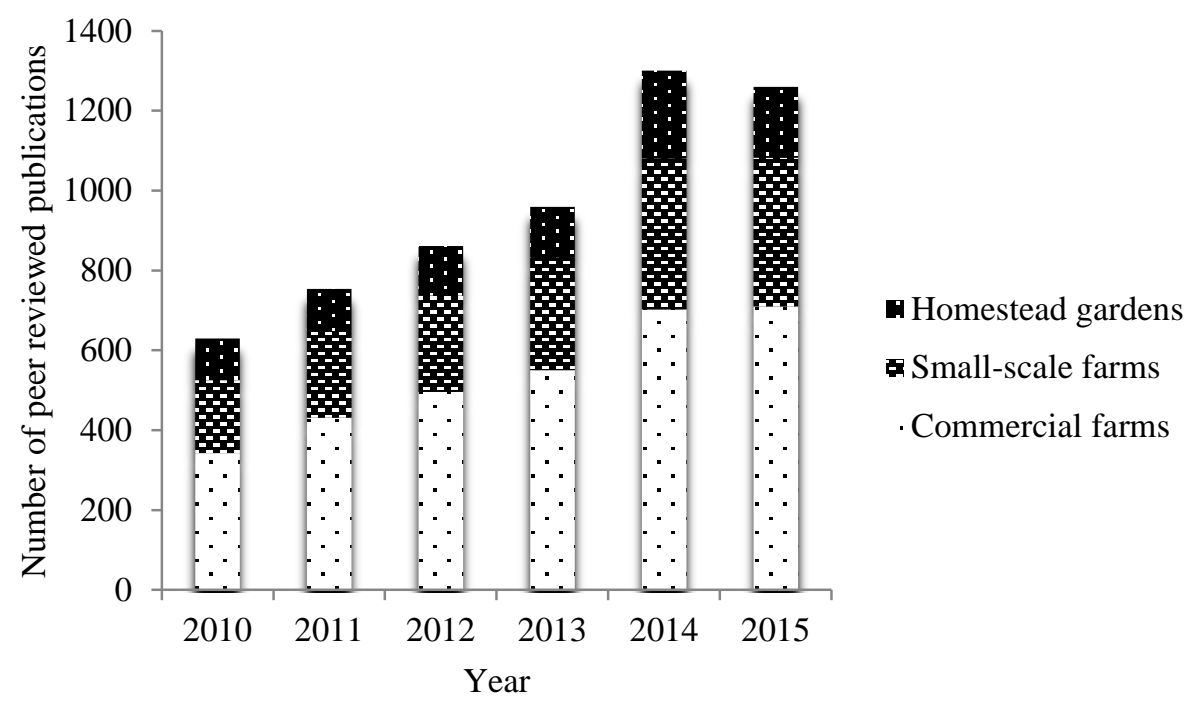

Figure 2. Peer reviewed articles concerning food safety issues at commercial and small-scal farms, and homestead gardens between 2010-2015.

\section{Small-scale farming}

A small farmer's operation is too small to attract the provision of the services needed to significantly increase productivity. Kirsten and van $\mathrm{Zyl}^{(55)}$ stated that turnover, rather than land size, could determine the size of the farm. In most cases, especially in South Africa, food safety protocols are not adhered to at these production systems. Food safety research at small-scale farms is low, accounting for 30\% of peer reviewed articles between 2010 and 2015 (Figure 2). This is despite the fact that a majority of the population living below the poverty datum line depends on produce from small-scale farms in many developing countries, South Africa included. 


\section{Homestead gardens}

Homestead garden farming falls under the smallest category of all vegetable production system. This is a farming system where a small plot of land $(<1 \mathrm{Ha})$ is used for production, but not on a scale that could be considered a profession. Very little information about food safety at homestead gardens is available. As shown in figure 2, 15\% of publications between 2010 and 2015 concerned homestead gardens. More research at homestead gardens can help reveal additional information about (1) presence and/or absence of foodborne pathogens, and (2) microbial profiles and alterations thereof, in water (irrigation and wash water) and on leafy greens brought about by pre- and post-harvest activities.

\section{Microbial Quality of Leafy Green Vegetables}

There are diverse microbial communities present on the phylloplane, as epiphytes and endophytes. The aerial parts of plants provide a habitat on the surfaces of the leaves for a diverse spectrum of microbes including bacteria, yeasts, filamentous fungi, ${ }^{(56)}$ protozoa and nematodes. ${ }^{(57)}$ The composition of these microbial communities are symbionts; they include those that have key benefits to the plants (mutualistic), and some that may negatively affect plant health (parasitic, which include all plant pathogens) while a host of others are potential human pathogens. ${ }^{(56,58)}$ Fungi are ephemeral occupants of the phylloplane, being present mainly as spores while other species such as bacteria inhabit the phylloplane for longer periods and are the most profuse. ${ }^{(57)}$

Similar to other microbes, bacterial communities are mainly affected by shifts in environmental conditions such as temperature and humidity ${ }^{(56)}$ as well as physical and nutritive properties of the phylloplane. This often results in disparities between bacterial populations 
among and within leafy green vegetables of similar classifications. ${ }^{(57)}$ Both culture dependent and independent methodologies have been used to analyze the microbial populations on the phylloplane ${ }^{(58)}$ to compensate for the limitations of the former more conventional techniques. ${ }^{(10)}$

Jackson et al. ${ }^{(58)}$ identified Pseudomonas, Pantoea, Chryseobacterium and Flavobacterium as ubiquitous genera; Agrobacterium, Erwinia, Leifsoniapoae and Xanthomonas as plant pathogens while Curtobacterium, Massilia, Methylobacterium, Serratia and Stenotrophomonas as non-pathogenic symbionts inhabiting the phyllosphere of leafy green vegetables, using culture dependent and independent based techniques. Four culturable bacterial phyla, Proteobacteria, Actinobacteria, Firmicutes, and Bacteroidetes, were identified using the Sanger sequencing technique on the surfaces of leafy greens in a study by Dees et al. ${ }^{(56)}$ These studies implicated that microbial diversity in the phylloplane of leafy greens was devoid of changes, regardless of culture or culture-independent analysis. However, Rastogi et al. ${ }^{(59)}$ found that up to $8.4 \%$ of the total bacterial population can be cultivated using real-time quantitative PCR (qPCR) and by enumerating colony-forming units (CFUs) on agar plates. It is important to note that in their work, Dees et al. ${ }^{(56)}$ did not identify any of the genera in the Enterobacteriaceae family that consist of potentially harmful human pathogens, such as Escherichia and Salmonella.

\section{Main Outbreaks Associated with Leafy Green Vegetables}

Most if not all foodborne pathogen outbreaks reported originated from commercial farming systems. $^{(60,61)}$ However, outbreaks from small-scale farming and homestead gardens are considered underreported. ${ }^{(5)}$ One of the comprehensive studies that explored potential links between the quality of irrigation water and the microbiological quality of food in small-scale farming systems was conducted by Gemmell and Schmidt ${ }^{(62)}$; the results of their study revealed 
poor microbiological quality of irrigation water and produce. Zoonotic bacteria that include several serotypes of S. enterica and verocytotoxin-producing E. coli O157 are amongst the biological threats leading most reported produce related occurrences. ${ }^{(63,64)}$

\section{Escherichia coli}

The third largest and deadliest E. coli outbreak reported in history occurred in 2011. This was associated with sprouts and caused the death of at least 54 people in Europe. ${ }^{(65)}$ The outbreak resulted in more than 3800 cases, the largest documented number of hemolytic uremic syndrome (HUS) cases in a single outbreak. Bagged leafy green salad was implicated as the pathogen carrier in the outbreak that caused seventeen reported cases and two fatalities in three American states. ${ }^{(66)}$ Luna-Gierke et al. ${ }^{(67)}$ studied the outbreaks of non-O157 Shiga toxin-producing E. coli infection and found that symptoms that included HUS were experienced by patients. The authors reported that Shiga toxin producing E. coli O157:H7 was responsible for the symptoms observed in the patients. A total of 606 epidemics were linked to leafy vegetables, causing 20,003 associated illnesses, and 19 deaths over a period from 1973-2012, according to an investigation conducted by Herman et al. ${ }^{(68)}$ The authors reported that leafy vegetable-linked epidemics were larger than those ascribed to other food products and pathogens often associated with the outbreaks of Shiga toxin-producing E. coli $(18 \%)$.

In 2015, epidemiologic evidence suggested that salad mixture was the likely source of an outbreak of the Shiga toxin-producing E. coli O157:H7. Ready-to-eat salads were implicated in a 2013 outbreak of E. coli O157:H7 in the United States of America that resulted in the hospitalization of 33 persons and no fatalities. ${ }^{(69)}$ An outbreak of E. coli O157:H7 infection linked to consumption of fresh spinach was reported in $2006 .{ }^{(69)}$ The traceback investigations 
during the outbreak of E. coli $\mathrm{O} 157: \mathrm{H} 7$ implicated the pre-packaged organic spinach and other leafy greens as the contaminants. The outbreak resulted in at least 33 infected persons. In 2010, shredded romaine lettuce from a processing facility was linked to an outbreak of two E. coli strains (O145 and O143) leading to several recalled products. ${ }^{(70)}$

\section{Salmonella and Listeria monocytogenes}

Other foodborne disease pathogens such as Salmonella ${ }^{(60)}$ and L. monocytogenes ${ }^{(71)}$ have also been reported on leafy green vegetables. From 1990 to 2005, Salmonella spp. has been found to be the causative pathogen in 44 leafy vegetable pathogen disease related outbreaks that led to at least 2908 illnesses. ${ }^{(72)}$ The author also mentioned that Salmonella spp. were frequently detected on mostly sprouts and green salads among others. In 2015,888 people were infected with the outbreak strains of Salmonella Poona, 191 hospitalized cases and at least four deaths were reported from different states of America. ${ }^{(69)}$ Whole genome sequencing (WGS) revealed similarities between isolates of $S$. Poona from ill people and contaminated cucumbers imported from Mexico. In 2004' an outbreak of Salmonella Thompson was recorded by the Norwegian authorities. ${ }^{(73)}$ Subsequently, 21 cases were reported following consumption of rucola lettuce and mixed salad. The outbreak spread to Sweden, where authorities detected the same Salmonella Thompson in rucola lettuce through the EU Rapid Alert System for Food and Feed. During an outbreak of listeriosis, L. monocytogenes strain serovar $4 \mathrm{~b}$ was isolated from 32 patients in Switzerland. ${ }^{(71)}$ Simultaneously, a food producing company detected a similar strain of $L$. monocytogenes contamination in ready-to-eat salads through its internal routine quality control. Subsequent investigations confirmed that ready-to-eat salad from this company was in all probability the source of the outbreak. ${ }^{(71)}$ 
Foodborne disease outbreaks of pathogens in developing countries are poorly reported or are not reported at all due to the sub-standard surveillance system in these countries. ${ }^{(74)}$ Conversely, the frequent report of foodborne disease outbreaks in developed countries such as the United States of America and Britain are largely attributable to better surveillance systems. Although the challenges associated with contamination of fresh produce and risks of foodborne disease outbreaks are experienced by both the developed and under-developed economies, the need for improved standards as well as developing better detection techniques persist. Moreover, sources of microbiological hazards such as irrigation water are a common challenge for both developed and developing countries.

\section{Pathogen Outbreaks Linked to Irrigation Water}

Irrigation water is a potential source of pathogens in foodborne disease outbreaks associated with leafy green vegetables. In 2013, an outbreak control team in Sweden identified the source of an enterohaemorrhagic E.coli outbreak associated with contaminated fresh salad. ${ }^{(75)}$ The trace-back investigation showed that contaminated irrigation water was the likely source of the outbreak. Irrigation water was reported as a likely source of contamination of iceberg lettuce that was implicated in another 2005 outbreak of E. coli O157:H7 in Sweden that resulted in 135 reported cases. ${ }^{(76)}$

An outbreak of E. coli $\mathrm{O} 157: \mathrm{H} 7$ linked to prepacked spinach was reported in the United States of America. ${ }^{(77)}$ The outbreak strain was recovered from river water used for irrigation and from animal fecal material. Therefore, the report concluded that river water functioned as a vector between the contaminated faeces and the irrigation wells used. Trace-back investigations also 
concluded that water intended for irrigation was accidentally contaminated with E. coli O157:H7, thereby causing an outbreak associated with shredded lettuce. ${ }^{(78)}$

Other reported foodborne disease outbreaks associated with fresh produce such as tomato ${ }^{(79)}$ and peppers $^{(80)}$ have been linked to irrigation water. However, sometimes evidence suggesting a link between irrigation water and an outbreak is circumstantial. Cooley et al. ${ }^{(81)}$ isolated a strain that was different from those associated outbreaks, while Mandrell ${ }^{(82)}$ could not directly authenticate that irrigation water was linked to an outbreak.

\section{Pathogen Transfer and Persistence on Produce}

Pre-harvest (soil, irrigation water and human handling) and post-harvest factors (harvesting equipment and processing wash water) can be a source of contaminating fresh produce, but the significance of the respective stages in the "farm-to-fork" array concerning pathogen contamination is not yet known. ${ }^{(1)}$ Manas et al. ${ }^{(83)}$ found that irrigation with water of poor microbiological quality resulted in significantly higher levels of contamination with Salmonella in lettuce compared to those irrigated with potable drinking water. Although polluted irrigation water is a primary source of fresh produce contamination, the pathway of the pathogen transfer to the leafy green vegetables is not yet clarified. Research has shown that the microbiological quality of irrigation water is a critical control point for food safety and for curbing the transmission of pathogens to humans, ${ }^{(84)}$ as in the case of leafy green vegetables. ${ }^{(85)}$ Research has demonstrated that pathogens such as E. coli O157:H7 can inhabit leaf surfaces or can penetrate into the soil when polluted water is used for irrigation. ${ }^{(86)}$ Therefore, the peripheral and, potentially, internal contamination of leafy greens polluted through water irrigation is a major prospective risk factor for consumption of the raw leafy green vegetables. This makes the use of 
microbiologically suitable irrigation water sources an essential preventative strategy. ${ }^{(87)}$ However, a recent study highlighted that internalization through roots or stomata of pathogens such as E. coli $\mathrm{O} 157: \mathrm{H} 7$ is unlikely given the relatively high pathogen doses required and for survival of any length of time. ${ }^{(88,89)}$

Various intervention strategies have been suggested to lessen the risk of produce contamination with human pathogens during irrigation. ${ }^{(84)}$ These interventions include a reduction in the influx of pathogen by direct input sources, treatment of water before storage (e.g., solar water disinfection) and manipulating irrigation programs. These practices assist in regulating the microbiological quality of water and aid in reducing the level of risk. ${ }^{(87)}$ The use of spray irrigation particularly close to harvest exposes the edible portion of leafy vegetables directly to contaminated water, ${ }^{(87,90)}$ while drip irrigation poses a lesser risk. The latter is particularly significant in fresh leafy greens that are consumed raw. ${ }^{(91)}$ The survival and thriving of entero-pathogens in the phylloplane has received increasing attention ${ }^{(53,54,63,64,89,92)}$ as focus is now shifted towards safety concern for fresh produce. The fate of foodborne pathogens such as Salmonella and E. coli O157:H7 has been investigated in pre- ${ }^{(92)}$ and post-harvest ${ }^{(93)}$ settings, respectively. The latter study reported that $E$. coli $\mathrm{O} 157: \mathrm{H} 7$ survived on lettuce stored at $4^{\circ} \mathrm{C}$ and were detected after 15 days, even when the initial inoculum was $10^{0}$ to $10^{1} \mathrm{CFU} / \mathrm{g}$. The research according to Wood et al. ${ }^{(54)}$ reported that nalidixic acid-resistant $E$. coli and non-pathogenic serotype $\mathrm{O} 157: \mathrm{H} 7$ strains inoculated by irrigation at $10^{4}$ to $10^{7} \mathrm{cfu} / 100 \mathrm{ml}$ survived on spinach for up to six days. Erickson et al. ${ }^{(94)}$ revealed that E. coli at $8 \log \mathrm{CFU} / \mathrm{ml}$ persisted for up to 27 days while Salmonella spp. at a $2.5 \mathrm{log} \mathrm{CFU} / \mathrm{ml}$ could persevere and contaminate the produce after spray irrigation. ${ }^{(92)}$ It is important to note, however, that these studies were conducted under 
different conditions and most likely contributing to their contrasting results. Erickson et al. ${ }^{(94)}$ was a field study where air currents would have accentuated desiccation stress to any pathogens residing on the plants, while Kisluk and Yaron ${ }^{(92)}$ used a greenhouse. In the latter study, survival of Salmonella did not last longer than 48 hrs due to the low pathogen dose.

Furthermore, according to Ongeng et al. ${ }^{(95)}$ E. coli O157:H7 and Salmonella spp. have been shown to penetrate into the tissue of cabbage leaves from the immediate soil environment under a commercial farming system. However, Erickson et al. ${ }^{(5)}$ studied the fate of E. coli O157:H7 and Salmonella present in the soil and the root of lettuce from home gardening practices. The authors inoculated E. coli O157:H7 and Salmonella with low and high concentration. Their results showed that the internalization of these pathogens into lettuce roots did not occur under practices that were typically encountered by home gardeners.

In a previous study, Erickson et $a l .{ }^{(89)}$ reported the occurrence of internalization of $E$. coli O157:H7 from the spinach and lettuce phyllospheres when inoculated with a high inoculum (7 to $8 \log \mathrm{CFU} / \mathrm{ml})$. Their result, however, showed that no internalization was observed in lettuce leaves at a low-dose inoculation ( 2.7 to $4.2 \log \mathrm{CFU} / \mathrm{ml})$. It has been demonstrated that enteropathogens can adapt and acclimatize to the conditions of the phylloplane environment, but they may be outcompeted by epiphytes, particularly if both isolates have similar nutrient requirements. ${ }^{(96,97)}$ Some epiphytes support the growth of entero pathogens on the phylloplane. For example, E. coli $\mathrm{O} 157: \mathrm{H} 7$ survival on the surface of lettuce leaf is aided by Wausteriapaucula ${ }^{(97)}$ Other epiphytic bacteria such as Entero bacterasburiae ${ }^{(97)}$ were linked to 
the presence of the downy mildew pathogen, ${ }^{(98)}$ which affects the survival of the entero pathogen (E. coli $\mathrm{O} 157: \mathrm{H} 7)$ on letuce leaves. ${ }^{(97)}$

The survival and persistence of these entero pathogens on the phylloplane thus has the potential to enhance chances of an infectious dose remaining at the point of consumption, if the cook-step is omitted; ${ }^{(96)}$ this makes it a major concern to public health. Despite challenges in the production of hygienically safe fresh produce, an increase in the consumption of fresh vegetables has been observed. This is mainly due to the increasing awareness of their health benefit to the consumer. ${ }^{(99)}$

\section{Pathogen Detection and Identification Methods Used for Irrigation Water and Leafy Green Vegetables}

The process of identifying and detecting pathogens was traditionally based on conventional microbiological methods. The conventional methods are mainly based on culturing of microorganisms on nutrient media subsequent to the biochemical testing ${ }^{(66)}$ and more recently, the molecular identification of the pathogens using techniques such as MALDITOF MS and PCR. ${ }^{(100)}$ Culture-based techniques are generally inexpensive and simple as the methods hinge on the capability of the microorganisms to be cultivated in culture media. Cultivating pathogens using conventional methods can yield preliminary results after 72 hrs. ${ }^{(101)}$ However, both viable but non-culturable pathogens, which could be present may not be detected by the culture-based technique owing to environmental pressures, and, thus, may present false negative results. ${ }^{(102)}$ Results by Du Plessis et al. ${ }^{(17)}$ showed many false positive results when selective media were used for isolation of presumptive E. coli, Salmonella, and L. monocytogenes following enrichment in appropriate media. The risk of foodborne pathogen transmission could increase 
due to the lack of novel scientific methods to correctly detect and identify pathogens ${ }^{(103)}$ in leafy green vegetables.

Matric Assisted Laser Desorption Ionization Time of Flight (MALDITOF) Mass Spectrometry

Numerous studies have shown the accuracy of using the MALDITOF MS technique to identify microorganisms. ${ }^{(104,105,106)}$ Studies have shown that this method is fast and appropriate for high throughput routine analysis. For instance, this procedure can be applied to identify Salmonella spp. ${ }^{(104,107)}$ and for the detection of plasmid insertion in E. coli. ${ }^{(108)}$ It has also been used to discriminate wild-type isolates from ampicillin-resistant E. coli. ${ }^{(106)}$ Hausdorf et al. ${ }^{(109)}$ in their research using MALDITOF MS for identification purposes, were able to reflect the cultivable microbial populations in a spinach-growing environment.

\section{PCR Techniques}

Amplification of nucleic acids ${ }^{(110)}$ using PCR based techniques has been used to detect and confirm identities of isolates. ${ }^{(111)}$ Compared to the culture methods, molecular based techniques have greater specificity and sensitivity producing more rapid and accurate results. However, it is important to note that despite benefits of recent advances in rapid detection methods, the presence of nucleic acids belonging to pathogenic microorganism(s) does not imply the presence of viable organism(s). Therefore, culture based techniques are required to establish the extent, if any, of a food safety risk. Despite the report of the unreliability and microbial underestimation of the culture-based methods leading to a shift towards molecular technology, a pre-enrichment step may be performed before the molecular analysis to increase the number of the target microorganisms in vegetable samples. ${ }^{(102)}$ This is necessary because inhibitors to the molecular 
assays are present in the sample extract and prevent detection at lower pathogen populations. Although very sophisticated and often fast, some molecular detection methods are generally only qualitative, not quantitative, due to this enrichment step, and therefore the data has limited value. Digital droplet (dd), ${ }^{(112)}$ multiplex ${ }^{(113)}$ and quantitative $(q){ }^{(114)}$ PCR techniques continue to be of growing importance in modern research programs. Yet these technologies have not been adopted in regulatory diagnostic systems, which still rely on traditional methods and prescribed standards.

The ddPCR technology is the latest method; it is based on partitioning, mimicking limiting dilution and Poisson statistics to compensate for the confines of qPCR. ${ }^{(112,115)}$ In ddPCR, the bulk reaction is apportioned into hundred thousand to millions of nanoliter (sometimes picoliter) reactions inside small chambers on a chip or within water in oil droplets preceding PCR amplification. ${ }^{(112)}$ This technology is not as affected by deferred amplification or inconsistency in $\mathrm{Cq}$ values as is $\mathrm{qPCR} ;^{(116)}$ hence, it is more precise than other PCR techniques $^{(115)}$ and less affected by PCR inhibitors. The multiplex PCR (mPCR) technique detects two or more pathogens in one assay.

Law et $a l .^{(103)}$ stated that mPCR offers a more rapid detection method compared to the conventional technique through the simultaneous amplification of multiple gene targets. Designing of the primers is critical for the development of mPCR, as the primer sets should have similar annealing temperatures to yield a successful assay. ${ }^{(101)}$ This detection approach is economically favorable as it reduces the total space required for handling a large number of samples. The technology has been used to detect foodborne pathogens in lettuce, ${ }^{(117)}$ milk and processed food. ${ }^{(113)}$ Chen et $_{\text {al }}{ }^{(118)}$ used the mPCR for the simultaneous detection of Salmonella enteritidis, Staphylococcus aureus, Shigella flexneri, L. monocytogenes, and E. coli O157:H7 
using five pairs of primers. Real-time PCR analysis on the other hand monitors the amplification of a targeted DNA molecule continuously in the entire reaction by measuring fluorescent signals. $^{(103)}$ The fluorescent systems such as SYBR green, TaqMan probes and molecular beacons have been developed for qPCR. ${ }^{(103)}$ It has also been reported in studies for the detection of Salmonella spp. and L. monocytogenes in food samples. ${ }^{(119)}$

\section{Next Generation Sequencing}

The recently developed high-throughput next generation sequencing (NGS) technology, such as 454 pyrosequencing of the small sub-unit (SSU) rRNA genes, offers a holistic comprehensive microbial community structure. ${ }^{(10)}$ Orgiazzi et $a l .{ }^{(120)}$ stated that although NGS technologies are not exempted from bias, they help investigate microbial diversity at an exceptional high level of resolution. Fungal populations in soil ${ }^{(121)}$ and freshwater lake ecosystems ${ }^{(122)}$ have been assessed using pyrosequencing technology. Chidamba and Korsten $^{(10)}$ used the pyrosequencing technology to investigate the bacterial diversity in river and RHRW that serves potable purposes in rural communities. Their study detected several bacterial phyla including Proteobacteria. Telias et al. ${ }^{(123)}$ studied the bacterial population diversity and variation in different spray water sources and that of tomato fruit phylloplane using the pyrosequencing technique. Their study was the first to use a NGS technology to investigate the bacterial populations on the fruit phylloplane of a tomato crop under two dissimilar spray water systems. Thus, the results exemplified an essential step concerning the improvement of science-based metrics for good agricultural practices. $^{(123)}$ 


\section{Genotypic and Phenotypic Characterizations}

Moreover, genotypic characterization of microbial isolates has been achieved using molecular methods such as enterobacterial repetitive intergenic consensus (ERIC) PCR analysis ${ }^{(17)}$ and (GTG)5-Rep-PCR. ${ }^{(16)}$ These methods are resolute in discriminating between microbial isolates and, as shown by recent articles, were able to distinguish among isolates from particular sampling sites and/or species; thus, they become helpful in linking microbial quality of fresh produce with contaminated irrigation water. ${ }^{(16,17,124)}$

Genotypic characterization using the aforementioned methods has been carried out to differentiate isolates originating from diverse sources, i.e., irrigation water, ${ }^{(16)}$ human, cattle, pigs and other sources. ${ }^{(125)}$ Phenotypic characterization of microbial pathogens ${ }^{(126)}$ using antimicrobial $^{2}$ susceptibility methods (i.e., the Kirby Bauer disk diffusion) ${ }^{(127)}$ have also been used, sometimes in conjunction with genotypic (ERIC and GTG $_{5}$-REPPCR) classifications. ${ }^{(16,17,124)}$ The simultaneous use of both genotypic and phenotypic classifications can enable the differentiation among pathogen isolates from a specific sampling site and/or species, and can also help to establish the source and link between contaminated fresh produce with polluted irrigation water. ${ }^{(17)}$ Overall, modern technology has now provided a platform of methods that can be used simultaneously or in tandem giving a more comprehensive analysis of the food safety status within the farm -to-fork continuum.

\section{Conclusions}

Food safety issues regarding irrigation water and leafy green vegetables are still a constant challenge to all relevant stakeholders. However, underreporting and knowledge gaps contribute to the unknown magnitude of this challenge. There are several outbreaks associated with leafy 
greens and linked to contaminated irrigation water. Reduced accessibility to good quality irrigation water is central to the production of potentially unsafe and contaminated fresh produce. This review concludes that RHRW is an alternative source water for irrigation of leafy green vegetables. Method validation and verification is important to ensure that detection methodologies are effective in food safety management systems. Food safety management tools and necessary education are necessities at all leafy green production systems. However, sanitary surveys and testing should be used simultaneously in these situations to complement existing strategies (GAPs).

\section{Acknowledgements}

We thank the assistance of Sphumelele Mkhize and Dennis Makuwa for their assistance in literature collection.

\section{Funding}

This study was part of a solicited research project (K5/1875/4: Evaluation of the risks associated with the use of rain-water harvested from rooftops, for domestic use and homestead food gardens; and groundwater for domestic use and livestock watering) funded by the Water Research Commission and co-funded by Department of Agriculture, Forestry, and Fisheries, Republic of South Africa.

\section{References}

1. Uyttendaele, M.; Jaykus, L.; Amoah, P.; Chiodini, A.; Cunliffe, D.; Jacxsens, L.; Holvoet, K.; Korsten, L.; Lau, M.; McClure, P.; Medema, G.; Sampers, I.; Jasti, P.R. 
Microbial hazards in irrigation water: Standards, norms, and testing to manage use of water in fresh produce primary production. Compr. Rev.in Food Sci. Food Saf. 2015, 14, 336-356.

2. World Health Organization (WHO). Microbiological hazards in fresh leafy vegetables and herbs: Meeting Report, Rome. Microbiol. Risk Assess. Series 2008, 14, 151.

3. Koike, S.; Cahn, M.; Cantwell, M.; Fennimore, S.; Lestrange, M.; Smith, R.; Takele, E. Spinach production in California. UC vegetable research and information center 2011, 16.

4. Buchholz, A.L.; Davidson, G.R.; Marks, B.P.; Todd, E.C.; Ryser, E.T. Quantitative transfer of Escherichia coli $\mathrm{O} 157: \mathrm{H} 7$ to equipment during small-scale production of fresh-cut leafy greens. J. Food Prot. 2012, 75, 1184-1197.

5. Erickson, M.C.; Liao, J.; Payton, A.S.; Webb, C.C.; Ma, L.; Zhang, G.; Flitcroft, I.; Doyle, M.P.; Beuchat, L.R. Fate of Escherichia coli O157:H7 and Salmonella in soil and lettuce roots as affected by potential home gardening practices. J. Sci. Food Agric. 2013, 93, 3841-3849. doi: 10.1002/jsfa.6321.

6. Food and Agricultural Organization. National food safety systems in Africa-A situation analysis. National food safety systems in Africa. 2008.

7. Jahan, S. Epidemiology of foodborne illness. Scientific, health and social aspects of the food industry. Valdez, $\quad$ B. (Ed.). In Tech 2012, 321-342. http://www.intechopen.com/books/scientific-health-and-social-aspects-of-the-foodindustry/epidemiology-offoodborne-illness. (Accessed January 8 2016). 
8. Gemmell, M.E.; Schmidt, S. Is the microbiological quality of the Msunduzi River (KwaZulu-Natal, South Africa) suitable for domestic, recreational, and agricultural purposes? Environ. Sci. Pollut. Res. 2013, 20, 6551-6562.

9. Ahmed, W.; Gardner, T.; Toze, S. Microbiological quality of roof-harvested rainwater and health risks: A review. J. Environ. Quality 2011, 40, 13-21.

10. Chidamba, L.; Korsten, L. Pyrosequencing analysis of roof-harvested rainwater and river water used for domestic purposes in Luthengele village in the Eastern Cape Province of South Africa. Environ. Monit. Assess. 2015a, 187, 41.

11. Suslow, T.V.; Oria, M.P.; Beuchat, L.R.; Garrett, E.H.; Parish, M.E.; Harris, L.J.; Farber, J.N.; Busta, F.F. Production practices as risk factors in microbial food safety of fresh and fresh cut produce. Compr. Rev. Food Sci. Food Saf. 2003, 2, 38-77.

12. Simmons, G.; Hope, V.; Lewis, G.; Whitmore, J.; Gao, W.Z. Contamination of potable roof-collected rainwater in Auckland, New Zealand. Water Res. 2001, 35, 1518-1524.

13. Ahmed, W.; Brandes, H.; Gyawali, P.; Sidhu J.P.S.; Toze S. Opportunistic pathogens in roof-captured rainwater samples, determined using quantitative PCR. Water Res. 2014, 5, $361-369$.

14. Baron, E.J. Conventional versus molecular methods for pathogen detection and the role of clinical microbiology in infection control. J. Clini. Microbiol. 2011, 49, 43.

15. Abakpaa, G.O.; Umoha, V.J.; Ameha, J.B.; Yakubua, S.E.; Ibekweb, A.M. Prevalence and antimicrobial susceptibility of pathogenic Escherichia coli $\mathrm{O} 157$ in fresh produce obtained from irrigated fields. Environ. Tech. Innov. 2015, 4, 1-7.

16. Aijuka, M.; Charimba, G.; Hugo, C.; Buys, E.M. Characterization of bacterial pathogens in rural and urban irrigation water. J. Water Health 2015. doi:10.2166/wh.2014.228. 
17. Du Plessis, E.; Duvenage, F.; Korsten, L. Determining the potential link between irrigation water quality and the microbiological quality of onions by phenotypic and genotypic characterization of Escherichia coli isolates. J. Food Prot. 2015, 78, 643-651.

18. Vörösmarty, C.J.; Green, P.; Salisbury, J.; Lammers, R.B. Global water resources: Vulnerability from climate change and population growth. Science 2000, 289, 284-288.

19. Zamxaka, M.; Pironcheva, G.; Muyima, N.Y.O. Microbiological and physico-chemical assessment of the quality of domestic water sources in selected rural communities of the Eastern Cape Province, South Africa. Water SA 2004, 30, 333-340.

20. Lee, S.H.; Levy, D.A.; Craun, G.F.; Beach, M.J.; Calderon, R.L. Surveillance for waterborne-disease outbreaks-United States, 1999-2000. Division of Parasitic Diseases National Center for Infectious Diseases, CDC, USA. Morbidity and Mortality Weekly Report. Surveillance Summaries (Washington, D.C.) 2002, 51, 1-47.

21. Kahinda, J.M.; Taigbenu, A.E.; Boroto, J. R. Domestic rainwater harvesting to improve water supply in rural South Africa. Phys. Chem. Earth PT A/B/C 2007, 32, 1050-1057.

22. James, J. Overview of microbial hazards in fresh fruit and vegetables operations, in microbial hazard identification in fresh fruit and vegetables. John Wiley and Sons, Inc. Hoboken. NJ. USA. 2006.

23. Center for disease control and prevention. Water sources. Atlanta, Georgia. 2009.

24. Taylor, R.G.; Scanlon, B.; Döll, P.; Rodell, M.; van Beek, R.; Wada, Y.; Longuevergne, L.; Leblanc, M.; Famiglietti, J.S.; Edmunds, M.; Konikow, L.; Green, T.R.; Chen, J.; Taniguchi, M.; Bierkens, M.F.P.; MacDonald, A.; Fan, Y.; Maxwell, R.M.; Yechieli, Y.; Gurdak, J.J.; Allen, D.M.; Shamsudduha, M.; Hiscock, K.; Yeh, P.J-F.; Holman, I.; Treidel, H. Ground water and climate change. Nat. Clim. Chang. 2013, 3, 322-329. 
25. Water Research Commission. Groundwater use potential for South Africa. Discussion paper. Report no. KV 23/2016. Pretoria, South Africa. 2016.

26. Council for Scientific and Industrial Research. A CSIR perspective on water in South Africa -2013. CSIR Report No. CSIR/NRE/PW/IR/2011/0012/A. 2013.

27. Pimentel, D.; Berger, B.; Filiberto, D.; Newton, M.; Wolfe, B.; Karabinakis. E.; Clark, S.; Poon, E.; Abbett, E.; Nandagopal S. Water resources: Agricultural and environmental issues. BioScience. 2004, 54, 909-918.

28. Pedrero, F.; Kalavrouziotis, I.; Alarcon, J. J.; Koukoulakis, P.; Asano, T. Use of treated municipal wastewater in irrigated agriculture. Review of some practices in Spain and Greece. Agric. Water Manage. 2010, 97, 1233-1241.

29. Xu, C. P.; Wu, W. Y.; Liu, H. L.; Shi, Y. W.; Yang, S. L. Effect of reclaimed water irrigation on the yield and quality of leaf vegetables. Irrig. Drain. 2010, 29, 23-26.

30. Jongman, M.; Korsten, L. Microbial quality and suitability of roof-harvested rainwater in rural villages for crop irrigation and domestic use. J. Water Health, 2016, 14. p.wh2016058.

31. Viljoen, M.F; Kundhlande, G.; Baiphethi, M.N.; Esterhuyse P.; Botha, J.J.; Anderson, J.J.; Minkley, G.W. An assessment of the social and economic acceptability of rainwater harvesting and conservation practices in selected peri-urban and rural communities. WRC Report No. 1648/1/12. Pretoria, South Africa. 2012.

32. Li, B.; Jackson, S.A.; Gangiredla, J.; Wang, W.; Liu, H.; Tall, B.D.; Beaubrun, J.J.; JayRussell, M.; Vellidis, G.; Elkins, C.A. Genomic evidence reveals numerous Salmonella enterica serovar Newport reintroduction events in Suwannee watershed irrigation ponds. Appl. Environ. Microbiol. 2015, 81, 8243-8253. 
33. World Business Council for Sustainable Development. Facts and trends: Water. ConchesGeneva, Switzerland. Earthprint Limited. 2015, 1-16.

34. Baleta, H.; Pegram, G. Water as an input in the food value chain. Understanding the food energy water nexus. WWF-SA, South Africa. 2014.

35. Neu, T.R.; Lawrence, J.R. Development and structure of microbial biofilms in river water studied by confocal laser scanning microscopy. FEMS Microbiol. Ecol. 1997, 24, 11-25.

36. Sigge, G.; Fitchet, T. Food safety in the limelight, South Africa. Food Rev. 2009, 36, 1416.

37. Ijabadeniyi, O.A.; Buys, E.M. Irrigation water and microbiological safety of fresh produce; South Africa as a case study: A review. Afri. J. Agric. Res. 2012, 7, 4848-4857.

38. Department of Water Affairs and Forestry. South African water quality guidelines (second edition). Vol. 4: Agricultural water use: irrigation, Pretoria. 1996.

39. Paruch, A.M.; Mæhlum, T.; Robertson, L. Changes in microbial quality of irrigation water under different weather conditions in southeast Norway. Environ. Proces. 2015, 2, $115-124$.

40. Kahinda, J.M.; Taigbenu A.E. Rainwater harvesting in South Africa: Challenges and opportunities. Phys. Chem. Earth 2011, 36, 968-976.

41. Helmreich, B.; Horn, H. Opportunities in rainwater harvesting. Desalination 2010, 248, 118-124.

42. Zhu, K.; Zhang, L.; Hart, W.; Liu, M.; Chen, H. Quality issues in harvested rainwater in arid and semi-arid Loess Plateau of northern China. J. Arid Environ. 2004, 57, 487-505. 
43. Dobrowsky, P.H.; De Kwaadsteniet, M.; Cloete, T.E.; Khan, W. Distribution of indigenous bacterial pathogens and potential pathogens associated with roof-harvested rainwater. Appl. Environ. Microbiol. 2014, 80, 2307-2316.

44. Barrow, C.J. Alternative irrigation: The promise of runoff agriculture. Earthscan. New York, USA. 2014.

45. Castro-Ibanez, I.; Gil, M.I.; Tudela, J.A.; Ivanek, R.; Allende, A. Assessment of microbial risk factors and impact of meteorological conditions during production of baby spinach in the Southeast of Spain. Food Microbiol. 2015, 49, 173-181.

46. Chigor, V.N.; Umoh, V.J.; Smith, S.I. Occurrence of Escherichia coli $\mathrm{O} 157$ in a river used for fresh produce irrigation in Nigeria. Afr. J. Biotechnol. 2010, 9, 178-182.

47. Benjamin, L.; Atwill, E.R.; Jay-Russell, M.; Cooley, M.; Carychao, D.; Gorski, L.; Mandrell, R.E. Occurrence of generic Escherichia coli, E. coli $\mathrm{O} 157$ and Salmonella spp. in water and sediment from leafy green produce farms and streams on the central California coast. Int. J. Food Microbiol. 2013, 165, 65-76.

48. Ahmed, W.; Sidhu, J.P.S.; Toze, S. An attempt to identify the likely sources of Escherichia coli harbouring toxin genes in rainwater tanks. Environ. Sci. Technol. 2012. $46,5193-5197$.

49. Sánchez, A.S.; Cohim, E.; Kalid, R.A. A review on physicochemical and microbiological contamination of roof-harvested rainwater in urban areas. Sust. Water Quality Ecol. 2015, 6, 119-137.

50. Maggioni, L.; von Bothmer, R.; Poulsen, G.; Branca, F. Origin and domestication of cole crops (Brassica oleracea L.): Linguistic and literary considerations1. Econ. Botany 2010, 64, 109-123. 
51. Linuqvist, K. On the origin of cultivated lettuce. Hereditas 1960, 46, 319-350.

52. Food and Agriculture Organization of the United Nations. Crop production: Statistics division. FAOSTAT. http://faostat.fao.org/. 2015. (Accessed February 23 2016).

53. Food and Agriculture Organization. Water and the Rural Poor: Interventions for improving livelihoods in Sub-Saharan Africa. Rome: FAO. http://www.fao.org/docrep/010/i0132e/i0132e00.htm. 2008 (Accessed January 12 2016).

54. Wood, J.D.; Bezanson, G.S.; Gordon, R.J.; Jamieson, R. Population dynamics of Escherichia coli inoculated by irrigation into the phyllosphere of spinach grown under commercial production conditions. Int. J Food Microbiol. 2010, 143, 198-204.

55. Kirsten, J.F.; Zyl, J.V. Defining small scale farmers in the South-African context. Agrekon, 1998, 37, 560-571.

56. Dees, M.W.; Lysøe, E.; Nordskog, B.; Brurberg, M.B. Bacterial communities associated with surfaces of leafy greens: Shift in composition and decrease in richness over time. Appl. Environ. Microbiol. 2015, 81, 1530-1539.

57. Lindow, S.E.; Brandl, M.T. Microbiology of the phyllosphere. Appl. Environ. Microbiol. 2003, 69, 1875-1883.

58. Jackson, C.R.; Randolph, K.C.; Osborn, S.L.; Tyler, H.L. Culture dependent and independent analysis of bacterial communities associated with commercial salad leaf vegetables. BMC Microbiol. 2013, 13, 274.

59. Rastogi, G.; Tech, J.J.; Coaker, G.L.; Leveau, J.H.J. A PCR-based toolbox for the culture-independent quantification of total bacterial abundances in plant environments. J. Microbiol. Methods 2010, 83, 127-132. 
60. Nygard, K.; Lassen, J.; Vold, L.; Andersson, Y.; Fisher, I.; Lofdahl, S.; Threlfall, J.; Luzzi, I.; Peters, T.; Hampton, M.; Torpdahl, M.; Kapperud, G.; Aavitsland, P. Outbreak of Salmonella Thompson infections linked to imported rucola lettuce. Foodborne Path. Dis. 2008, 5, 165-173.

61. Center for Disease Control and Prevention. List of selected multistate foodborne outbreak investigations. Atlanta, Georgia. 2016.

62. Gemmell, M.E.; Schmidt, S. Potential links between irrigation water quality and microbiological quality of food in subsistence farming in KwaZulu-Natal, South Africa. Mendez-Vilas, A. (Ed.). Current research, Technol. Edu, Topics in Appl. Microbiol. and Microbial Biotech. FORMATEX 2010, 1190-1195.

63. Olaimat, A.N.; Holley, R.A. Factors influencing the microbial safety of fresh produce: A review. Food Microbiol. 2012, 32, 1-19.

64. Buck, J.W.; Walcott, R.R.; Beuchat, L.R. Recent trends in microbiological safety of fruits and vegetables. Plant Health Prog.. doi:10.1094/PHP-2003-0121-01-RV. 2003

65. Buchholz, U.; Bernard, H.; Werber, D.; Böhmer, M.M.; Remschmidt, C.; Wilking, H.; Deleré, Y.; an der Heiden, M.; Adlhoch, C.; Dreesman, J.; Ehlers, J. German outbreak of Escherichia coli O104: H4 associated with sprouts. N. Engl. J. Med. 2011, 365(19), 1763-1770.

66. Marder, E.P.; Garman, K.N.; Ingram, L.A.; Dunn. J.R. 2014. Multistate outbreak of Escherichia coli O157:H7 associated with bagged salad. Foodborne Path. Dis. 2014, 11, 593-595. 
67. Luna-Gierke, R.E.; Griffin, P.M.; Gould, L.H.; Herman, K.; Bopp, C.A.; Strockbine, N.; Mody, R.K. Outbreaks of non-O157 Shiga toxin-producing Escherichia coli infection: USA. Epidemiol. Infect. 2014, 142, 2270-2280.

68. Herman, K.M.; Hall, A.J.; Gould, L.H. Outbreaks attributed to fresh leafy vegetables, United States, 1973-2012. Epidemiol. Infect. 2015, 143, 3011-3021.

69. Center for Disease Control and Prevention. List of selected multistate foodborne outbreak investigations. Atlanta, Georgia. 2016.

70. Center for Disease Control and Prevention. Multistate outbreak of human E. coli O145 infections linked to shredded romaine lettuce from a single processing facility. Atlanta, Georgia. $\quad$ http://www.cdc.gov/ecoli/2010/shredded-romaine-5-21-10.html. $\quad 2010$. (Accessed January 10 2016).

71. Stephan, R.; Althaus, D.; Kiefer, S.; Lehner, A.; Hatz, C.; Schmutz, C.; Jost, M.; Gerber, N.; Baumgartner, A.; Hachler, H.; Mausezahl-Feuz, M. Foodborne transmission of Listeria monocytogenes via ready-to-eat salad: A nationwide outbreak in Switzerland, 2013-2014. Food Control, 2015, 57, 14-17.

72. Smith deWaal, C.; Bhuiya, F. Outbreaks by the numbers: Fruits and vegetables 19902005. Center for Science in the Public Interest. Washington, DC. 2009.

73. Nygard, K.; Lassen, J.; Vold, L.; Andersson, Y.; Fisher, I.; Lofdahl, S.; Threlfall, J.; Luzzi, I.; Peters, T.; Hampton, M.; Torpdahl, M.; Kapperud, G.; Aavitsland, P. Outbreak of Salmonella Thompson infections linked to imported rucola lettuce. Foodborne Path. Dis. 2008, 5, 165-173.

74. Akhtar, S.; Sarker, M.R.; Hossain, A. Microbiological food safety: A dilemma of developing societies. Crit. Rev. in microbial. 2014, 40, 348-359. 
75. Edelstein, M.; Sundborger, C.; Hergens, M.P.; Ivarsson, S.; Dryselius, R.; Insulander, M.; Jernberg, C.; Hutin, Y.; Wallensten, A. Barriers to trace-back in a salad-associated EHEC outbreak, Sweden, June 2013. PLoS currents 2013, 6 . http://currents.plos.org/outbreaks/article/barriers-to-trace-back-in-a-salad-associatedehec-outbreak-swedenjune-2013./ (Accessed 2014 September 25).

76. Soderstrom, A.; Osterberg, P.; Lindqvist, A.; Jonsson, B.; Lindberg, A.; Blide Ulander, S.; Welinder-Olsson, C.; Lofdahl, S.; Kaijser, B.; De Jong, B. A large Escherichia coli O157 outbreak in Sweden associated with locally produced lettuce. Foodborne Pathog. Dis. 2008, 5, 339-349.

77. California Department of Health Services and United States Food and Drug Administration. Investigation of an Escherichia coli $\mathrm{O} 157: \mathrm{H} 7$ outbreak associated with Dole pre-packaged spinach.

2007. http://www.cdc.gov/nceh/ehs/Docs/Investigation_of_an_E_Coli_Outbreak_Associated_w ith_Dole_Pre-Packaged_Spinach.pdf. (Accessed 2016 November 1).

78. United States Food and Drug Administration and California Food Emergency Response Team. Investigation of the Taco John's Escherichia coli O157:H7 Outbreak associated with iceberg lettuce. Department of Health, Sacramento, CA. 2008, 41 .

79. Greene, S.K.; Daly, E.R.; Talbot, E.A.; Demma, L.J.; Holzbauer, N.; Patel, N.J.; Hill, T.A.; Walderhaug, M.A.; Hoekstra, R.; Lynch, M.F.; Painter, J.A. Recurrent multistate outbreak of Salmonella Newport associated with tomatoes from contaminated fields, 2005. Epidemiol. Infect. 2008, 136, 157-165. 
80. Centers for Disease Control and Prevention. Outbreak of Salmonella serotype Saintpaul infections associated with multiple raw produce items-United States, 2008. MMWR 2008, 57, 929-934.

81. Cooley, M.; Carychao, D.; Crawford-Miksza, L.; Jay, M.T.; Myers, C.; Rose, C.; Keys, C.; Farrar, J.; Mandrell, R.E. Incidence and tracking of Escherichia coli O157:H7 in a major produce production region in California. PLoS One 2007, 2. http://www.plosone.org/article/info\%3Adoi\%2F10.1371\%2Fjournal.pone.0001159.

82. Mandrell, R.E. Tracing pathogens in fruit and vegetable production chains. In "Tracing pathogens in the food chain" (S. Brul, P. M. Fratamico, and T. McMeekin, Eds.), Woodhead Publishing Ltd., Cambridge, UK. 2011, 548-595.

83. Manas, P.; Castro, E.; De Las Heras, J. Irrigation with treated wastewater: Effects on soil, lettuce (Lactuca sativa) crop and dynamics of microorganisms. J. Environ. Sci. Health Part A 2009, 44, 1261-1273.

84. Pachepsky, Y.; Shelton, D.R.; McLain, J.E.T.; Patel, J.; Mandrell, R.E. Irrigation waters as a source of pathogenic microorganisms in produce: A review. Adv. in Agronomy 2011, 113, 74-105.

85. Allende, A.; Monaghan, J. Irrigation water quality for leafy crops: A perspective of risks and potential solutions. Int. J. Environ. Res. Public Health 2015, 12, 7457-7477.

86. Chitarra, W.; Decastelli, L.; Garibaldi, A.; Gullino, M.L. Potential uptake of Escherichia coli $\mathrm{O} 157: \mathrm{H} 7$ and Listeria monocytogenes from growth substrate into leaves of salad plants and basil grown in soil irrigated with contaminated water. Int. J. Food Microbiol. 2014, 189, 139-145. 
87. Gil, M.I.; Selma, M.V.; Suslow, T.; Jacxsens, L.; Uyttendaele, M.; Allende, A. Pre- and postharvest preventive measures and intervention strategies to control microbial food safety hazards of fresh leafy vegetables. Crit. Rev. Food Sci. Nutri. 2015, 55, 453 -468.

88. Erickson, M.C.; Webb, C.C.; Davey, L.E.; Payton, A.S.; Flitcroft, I.D.; Doyle, M.P. Biotic and abiotic variables affecting internalization and fate of Escherichia coli O157:H7 isolates in leafy green roots. J. Food Prot. 2014, 77, 872-879.

89. Erickson, M.C.; Webb, C.C.; Davey, L.E.; Payton, A.S.; Flitcroft, I.D.; Doyle, M.P. Internalization and fate of Escherichia coli $\mathrm{O} 157: \mathrm{H} 7$ into leafy green phyllosphere tissue using various spray conditions. J. Food Prot. 2014, 77, 713-721

90. Suslow, T.V. Standards for irrigation and foliar contact water. An initiative of the pew $\begin{array}{lll}\text { charitable } & \text { trusts } & \text { at }\end{array}$ University.http://www.producesafetyproject.org/admin/assets/files/Water-Suslow-1.pdf. 2010. (Accessed February 10 2015).

91. Jones, S.; Shortt, R. Improving on-farm food safety through good irrigation practices. Ontario Ministry of Agriculture, Food and Rural affairs. Ontario, Canada. 2005.

92. Kisluk, G.; Yaron, S. Presence and persistence of Salmonella enterica serotype Typhimurium in the phyllosphere and rhizosphere of spray-irrigated parsley. Appl. Environ. Microbiol. 2012, 78, 4030-4036.

93. Beuchat, L.R. Survival of enterohaemorrhagic Escherichia coli O157:H7 in bovine faeces applied to lettuce and the effectiveness of chlorinated water as a disinfectant. J. Food Prot. 1999, 62, 845-849.

94. Erickson, M.C.; Webb, C.C.; az-Perez, J.C.; Phatak, S.C.; Silvoy, J.J.; Davey, L.; Payton, A.S.; Liao, J.; Ma, L.; Doyle, M.P. Surface and internalized Escherichia coli O157:H7 on 
field-grown spinach and lettuce treated with spray-contaminated irrigation water. J. Food Prot. 2010, 73, 1023-1029.

95. Ongeng, D.; Vasquez, G.A.; Muyanja, C.; Ryckeboer, J.; Geeraerd, A.H.; Springael, D. Transfer and internalisation of Escherichia coli O157:H7 and Salmonella enterica serovar Typhimurium in cabbage cultivated on contaminated manure-amended soil under tropical field conditions in Sub-Saharan Africa. Int. J. Food Microbiol. 2011, 145, 301-310.

96. Heaton, J.C.; Jones, K. Microbial contamination of fruit and vegetables and the behaviour of enteropathogens in the phyllosphere: A review. J. Appl. Microbiol. 2008, 104, 613626.

97. Cooley, M.B.; Chao, D.; Mandrell, R.E. Escherichia coli O157:H7 survival and growth on lettuce is altered by the presence of epiphytic bacteria. J. Food Prot. 2006, 69, 23292335.

98. Simko, I.; Zhou, Y.; Brandl, M.T. Downy mildew disease promotes the colonization of romaine lettuce by Escherichia coli O157:H7 and Salmonella enterica. BMC Microbiol. 2015, $15,19$.

99. Betts, R. Microbial update: fruit and salad. Int. Food Hyg. 2014, 25, 9-12.

100. Pinto, L.; Poeta, P.; Radhouani, H.; Coelho, C.; Carvalho, C.; Rodrigues, J.; Torres, C.; Vitorino, R.; Domingues, P.; Igrejas, G. Proteomic study in an Escherichia coli strain from seagulls of the Berlengas Natural Reserve of Portugal. Genetics 2011, 1, 36-41.

101.Zhao, X.; Lin, C.W.; Wang, J.; Oh, D.H. Advances in rapid detection methods for foodborne pathogens. J. Microbiol. Biotechnol. 2014, 24, 297-312. 
102. Mendes Silva, D.; Domingues, L. On the track for an efficient detection of Escherichia coli in water: A review on PCR-based methods. Ecotoxicol. Environ. Saf. 2015, 113, 400-411.

103. Law, J.W.; Mutalib N.; Chan, K.; Lee, L. Rapid methods for the detection of foodborne bacterial pathogens: Principles, applications, advantages and limitations. Front. in Microbiol. 2015, 5, 1-19.

104. Dieckmann, R.; Strauch, E.; Alter, T. Rapid identification and characterization of Vibrio species using whole-cell MALDI-TOF mass spectrometry. J. Appl. Microbiol. 2010, 109, 199-211.

105. Decristophoris, P.; Fasola, A.; Benagli, C.; Tonolla, M.; Petrini, O. Identification of Staphylococcus intermedius group by MALDI-TOF-MS. Syst. Appl. Microbiol. 2011, $34,45-51$.

106. Chidamba, L.; Korsten, L. A scoping study on the prevalence of Escherichia coli and Enterococcus species in harvested rainwater stored in tanks. Water SA, 2015b, 41, 501508.

107. Gomba, A.; Chidamba, L.; Korsten, L. Prevalence and serovar diversity of Salmonella spp. in primary horticultural fruit production environments. Food Control 2016, 69, 1316.

108. Neuhof, T.; Dieckmann, R.; Druzhinina, I.S.; Kubicek, C.P.; Von Dohren, H. Intact-cell MALDI-TOF mass spectrometry analysis of peptaibol formation by the genus Trichoderma/Hypocrea: can molecular phylogeny of species predict peptaibol structures? Microbiol. 2007, 153, 3417-3437. 
109. Hausdorf, L.; Mundt, K.; Winzer, M.; Cordes, C.; Frohling, A.; Schlu ter, O.; Klocke, M. Characterization of the cultivable microbial community in a spinach-processing plant using MALDITOF MS. Food Microbiol. 2013, 34, 406-411.

110. Girones, R.; Ferrús, M.A.; Alonso, J. L.; Rodriguez-Manzano, J.; Calgua, B.; Corrêa Ade, A.; Hundesa, A.; Carratala, A.; Bofill-Mas, S. Molecular detection of pathogens in water- The pros and cons of molecular techniques. Water Res. 2010, 44, 4325-4339.

111. Germini, A.; Masola, A.; Carnevali, P.; Marchelli, R. Simultaneous detection of Escherichia coli O175:H7, Salmonella spp., and Listeria monocytogenes by multiplex PCR. Food Control 2009, 20, 733-738.

112. Cao, Y.; Raith, M.R.; Griffith, J.F. Droplet digital PCR for simultaneous quantification of general and human-associated fecal indicators for water quality assessment. Water Res. 2015, 70, 337-349.

113. Garrido, A.; Chapela, M.J.; Roman, B.; Ferreira, M.; Lago, J.; Vieites, J.M.; Cabado, A.G. Development of a multiplex real-time PCR method for simultaneous detection of Salmonella enterica, Shigella flexneri and Listeria monocytogenes in processed food samples. Eur. Food Res. Technol. 2012, 234, 571-580.

114. Garrido, A.; Chapela, M-J.; Román, B.; Fajardo, P.; Vieites, J.M.; and Cabado, A.G. Inhouse validation of a multiplex real-time PCR method for simultaneous detection of Salmonella spp., Escherichia coli 0157 and Listeria monocytogenes. Int. J. Food Microbiol. 2013, 164, 92-98.

115. Hindson, C.M.; Chevillet, J.R.; Briggs, H.A.; Gallichotte, E.N.; Ruf, I.K.; Hindson, B.J.; Vessella, R.L.; Tewari, M. Absolute quantification by droplet digital PCR versus analog real-time PCR. Nat. Methods 2013, 10, 1003-1005. 
116. Whale, A.S.; Hugget, J.F.; Cowen, S.; Speirs, V.; Shaw, J.; Ellison, S.; Foy, C.A.; Scott, D.J. Comparison of microfluidic digital PCR and conventional quantitative PCR for measuring copy number variation. Nucleic Acid Res. 2012, 40, 82-89.

117. Koseki, S.; Mizuno, Y.; Kawasaki, S.; Yamamoto, K.A. Survey of iceberg lettuce for the presence of Salmonella, Escherichia coli O157:H7, and Listeria monocytogenes in Japan. J. Food Prot. 2011, 74, 1543-1546.

118. Chen, J.; Tang, J.; Liu, J.; Cai, Z.; Bai, X. Development and evaluation of a multiplex PCR for simultaneous detection of five foodborne pathogens. J. Appl. Microbiol. 2012, $112,823-830$.

119. Ruiz-Rueda, O.; Soler, M.; Calvó, L.; García-Gil, J. L. Multiplex real-time PCR for the simultaneous detection of Salmonella spp. and Listeria monocytogenes in food samples. Food Anal. Methods, 2011, 4, 131-138.

120. Orgiazzi, A.; Bianciotto, V.; Bonfante, P.; Daghino, S.; Ghignone, S.; Lazzari, A. 454 pyrosequencing analysis of fungal assemblages from geographically distant, disparate soils reveals spatial patterning and a core mycobiome. Diversity, 2013, 5, 73-98.

121.Lim, Y.M.; Kim, B.K.; Kim, C.; Jung, H.S.; Kim, B.; Lee, J.; Chun. J. Assessment of soil fungal communities using pyrosequencing. J. Microbiol. 2010, 48, 284-289.

122. Monchy, S.; Sanciu, G.; Jobard, M.; Rasconi, S.; Gerphagnon, M.; Chabé, M.; Cian, A.; Meloni, D.; Niquil, N.; Christaki, U.; Viscogliosi, E.; Sime-Ngando, T. Exploring and quantifying fungal diversity in freshwater lake ecosystems using rDNA cloning/ sequencing and SSU tag pyrosequencing. Environ. Microbiol. 2011, 13, 1433-1453. 
123. Telias, A.; White, J.R.; Pahl, D.M.; Ottesen, A.R.; Walsh, C.S. Bacterial community diversity and variation in spray water sources and the tomato fruit surface. BMC Microbiol. 2011, 11, 1-13.

124. Jongman, M.; Korsten, L. Genetic diversity and antibiotic resistance of Escherichia coli isolates from different leafy green production systems. J. Food Prot. doi:10.4315/0362028X.JFP-16-117. 2016, 79, 1846-1853

125. Ateba, C.N.; Mbewe, M. Genotypic characterization of Escherichia coli O157:H7 isolates from different sources in the North-West Province, South Africa, using enterobacterial intergenic concencus PCR analysis. Int. J. Mol. Sci. 2014, 15, 9735-9747. doi:10.3390/ijms 15069735.

126. Holvoet, K.; Samper, I.; Callens, B.; Dewulf, J.; Uyttendale, M. Moderate prevalenceof antimicrobial resistance in Escherichia coli isolates from lettuce, irrigation water, andsoil. Appl. Environ. Microbiol. 2013, 79, 6677-6683.

127. Bauer, A.W.; Kirby, W.M., Sherris, J.C.; Turck, M. Antibiotic susceptibility testing by a standardized single disk method. Tech. Bull. Regist. Med. Technol. 1966, 36, 49-52. 